\section{A novel view of global warming}

\section{State of Fear}

by Michael Crichton

HarperCollins: 2004. 603 pp. \$27.95, $£ 17.99$

\section{Myles Allen}

Jo Public is smarter than we think. When I reviewed the film The Day After Tomorrow for Nature $(429,347-348)$, I said that it couldn't really do any harm, and it made geophysics look cool, so we shouldn't worry about the liberties it took with thermodynamics. I was wrong. Surveys of public opinion conducted before and after the film was released found that it made people think climate change is less likely: "If that's what it's all about, there's no way..." Michael Crichton's latest blockbuster, State of Fear, is also on the theme of global warming and is, in its own way, equally likely to mislead the unwary.

A long plane journey to the 10th Conference of the Parties of the United Nations Framework Convention on Climate Change was the perfect excuse to read this book. "So," Crichton's hero (an MIT professor who moonlights as a secret-service agent) would interrupt to declare, "he's one of them." The central thesis of the book is that we scientists are collaborating with the environmental movement, bending facts in a cavalier manner to fit our mad global-warming theories - and when the facts won't bend far enough, we make them up.

It is a sad indictment of the image of modern science that many readers will find this thesis entirely plausible, even if they don't buy the specific scenario of ecoterrorists setting off a train of synthetic natural disasters to provide mood music for an international climate conference. Crichton himself clearly accepts it, and desperately wants his reader to do the same, to the extent that he keeps freezing the action to provide lengthy sermons, complete with graphics, about all that is wrong with the evidence for global warming. The ruse that Crichton uses to bring in these sermons is neat: a team of worried environmental lawyers, preparing a case against the US government, rehearse possible arguments that might be used by the defence.

Crichton has evidently been inspired by the eco-conspiracy theories of Bjørn Lomborg's The Skeptical Environmentalist. Both books demonstrate how intelligent reviewers, given a complex issue and sufficiently rich literature, can find support for whatever position they care to adopt. For example, Crichton opens with the fact that glaciers are advancing in Iceland and Norway, failing to mention that they are retreating just about everywhere else outside the polar ice caps.

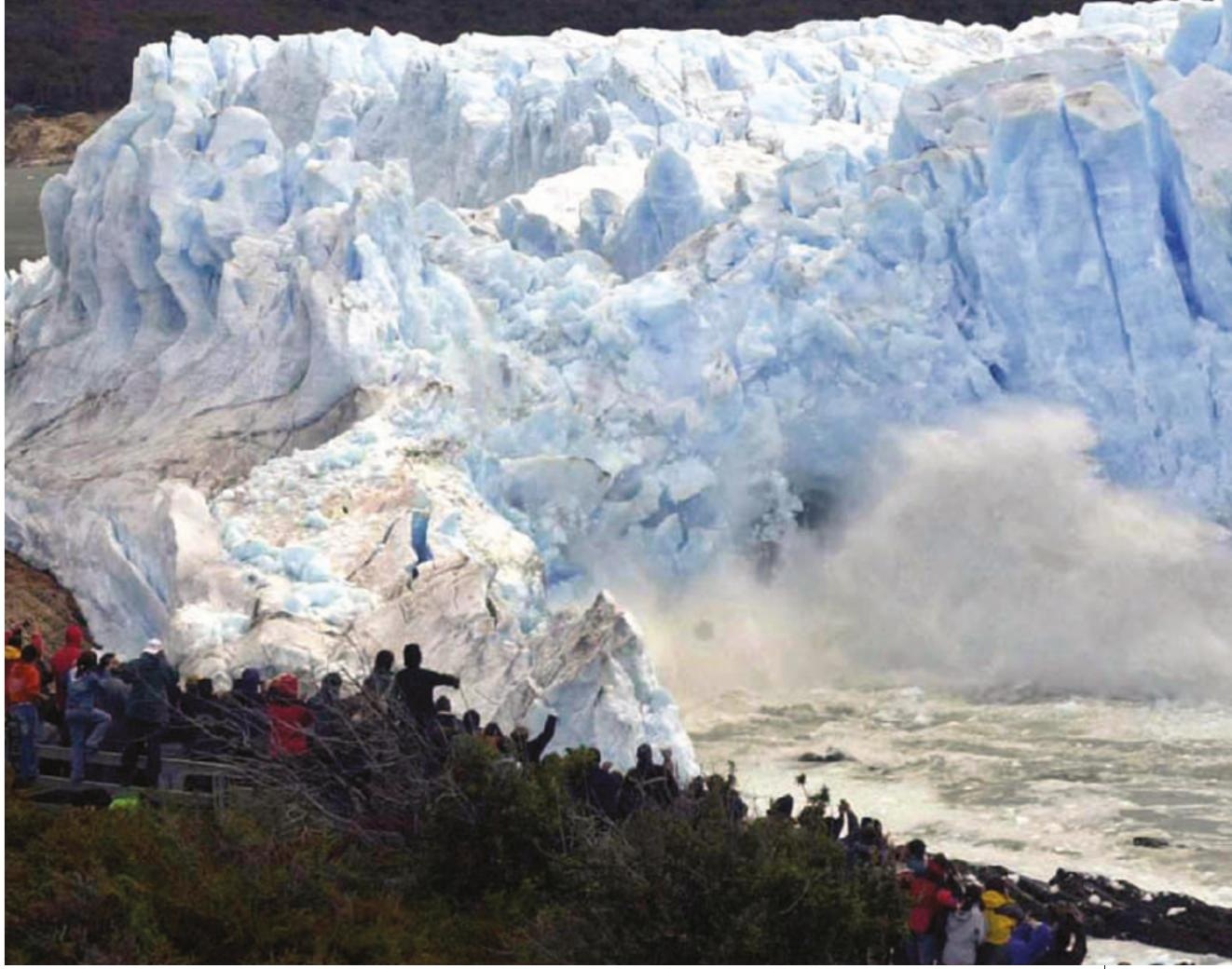

Cold comfort: Argentina's Perito Moreno glacier is still advancing, but many others are in retreat.

Given the thousands of temperature records available on the Internet, it is unsurprising that he can find some to support the claim that much of the apparent warming during the twentieth century is due to urbanization.

Occasionally there is a straightforward error, such as the claim that the scientific community cannot explain why temperatures rose early in the twentieth century, flattened off and then rose again, while carbon dioxide levels were rising all the time - the explanation, a combination of natural and other anthropogenic drivers, has been available for years. And Crichton cannot resist bringing in a tsunami (presumably a precondition of the movie deal), although even he must know that no one has ever claimed a link between tsunamis and climate change. Although this is a work of fiction, Crichton's use of footnotes and appendices is clearly intended to give an impression of scientific authority. He appears to have succeeded, as the book has already been respectfully cited in the US Senate as a serious contribution to the climate-change debate.

Crichton does make some nice observations, for example about the outdoor gear worn to climate conferences by people who never stray from a computer (let's face it, we're badly paid office workers). With his medical background, he also finds the lack of double-blind studies in climate research troubling. Here he has a point, but the solution is far from obvious, given that we are all studying a single patient, and we learn in the first term of graduate school how the patient is believed to have behaved over the past century. Having contentious results re-analysed by independent groups is an excellent idea; the US National Science Foundation, to its credit, recently did just this with results from the Microwave Sounding Unit. But Crichton is strangely silent on this one, presumably because the results were not to his liking.

Books such as State of Fear highlight the question of whether there is any such thing as a dispassionate scientific review. Is it just a matter of political taste whether to believe Crichton and Lomborg over, say, the Intergovernmental Panel on Climate Change (IPCC)? If the scientific community is to recover its standing in the world, we have to stand up to the pseudo-democratic vogue for treating everyone, regardless of expertise, as just another stakeholder. No science is infallible, but there is good science and there is bad science, and it is not just a matter of opinion which is which. A hallmark of good science must be the way it treats uncertainty. The IPCC said in 2001 that there is up to a one-in-three chance that the warming observed over the twentieth century might be "entirely natural in origin". If Crichton and Lomborg were equally frank about the chances of their basic premises turning out to be wrong, their scientific views would be a lot more credible.

But in the end, State of Fear is about people: the transformation of Peter Evans, a lawyer who drives a clean 'hybrid' car and is too shy to admit he has never fired a gun, into a gun-toting carbon-junkie at the wheel of a fuel-hungry sports utility vehicle. It definitely helps him get the girls. "There was something about him. Some surprising quality she hadn't noticed before." He had become... a climate sceptic.

That pretty much says it all about this book: Viagra for climate sceptics.

Myles Allen is in the Climate Dynamics Group, Department of Physics, University of Oxford,

Parks Road, Oxford OX1 3PU, UK. 